NBER WORKING PAPER SERIES

FISCAL LIMITS IN ADVANCED ECONOMIES

Eric M. Leeper

Todd B. Walker

Working Paper 16819

http://www.nber.org/papers/w16819

NATIONAL BUREAU OF ECONOMIC RESEARCH
1050 Massachusetts Avenue
Cambridge, MA 02138
February 2011

Prepared for the 39th Australian Conference of Economists. We thank Huixin Bi for helpful discussions. The views expressed herein are those of the authors and do not necessarily reflect the views of the National Bureau of Economic Research.

NBER working papers are circulated for discussion and comment purposes. They have not been peerreviewed or been subject to the review by the NBER Board of Directors that accompanies official NBER publications.

(C) 2011 by Eric M. Leeper and Todd B. Walker. All rights reserved. Short sections of text, not to exceed two paragraphs, may be quoted without explicit permission provided that full credit, including (C notice, is given to the source. 
Fiscal Limits in Advanced Economies

Eric M. Leeper and Todd B. Walker

NBER Working Paper No. 16819

February 2011

JEL No. E30,E62,E63,H60

\begin{abstract}
$\underline{\text { ABSTRACT }}$
Aging populations in advanced economies are placing ever-increasing demands on government spending in the form of old-age benefits. Economies that have promised substantially more benefits than they have made provision to finance are heading into a prolonged era of fiscal stress. Unresolved fiscal stress raises the possibility that the economies will hit their fiscal limits where taxes and spending no longer adjust to stabilize debt. In such economies, monetary policy may lose its ability to control inflation and influence the economy in the usual ways. The paper discusses models of fiscal limits and their implications and lays out a research agenda to integrate political economy and empirical considerations with general equilibrium models of monetary and fiscal interactions.
\end{abstract}

Eric M. Leeper

Department of Economics

304 Wylie Hall

Indiana University

Bloomington, IN 47405

and Monash University, Australia

and also NBER

eleeper@indiana.edu

Todd B. Walker

Department of Economics

105 Wylie Hall

Indiana University

Bloomington, IN 47405

walkertb@indiana.edu 


\title{
Fiscal Limits in Advanced Economies*
}

\author{
Eric M. Leeper ${ }^{\dagger}$ and Todd B. Walker ${ }^{\ddagger}$
}

\section{INTRODUCTION}

Extreme fiscal stress and fears of outright sovereign debt default were once the exclusive domains of emerging economies, and a sizeable literature has grown up to understand the causes and consequences of those fiscal crises. But these are topsy-turvy times. Emerging economies are in good fiscal shape, while advanced economies are heading into a prolonged era of fiscal stress. Important structural differences between emerging and advanced economies may limit applying insights from the emerging markets literature to the problems that advanced economies face.

Large adverse external shocks frequently precipitate sovereign debt crises in emerging economies. ${ }^{1}$ Emerging economies typically have weak fiscal infrastructures that make the countries' government finances especially susceptible to shocks originating outside their economies - large swings in commodity prices, sudden stops of capital inflows, sharp changes in real exchange rates - as well as to tax evasion and the swift movement of economic activity underground. Weak fiscal infrastructures, combined with fragile political systems, fixed exchange rates, and government debt denominated in foreign currency, can leave the economy with no choice but to default or substantially restructure its sovereign debt obligations. Important ingredients in these crises are: they usually come on suddenly, with few early warning signals; following a default, the country is temporarily locked out of credit markets, making default potentially costly in terms of output losses; several emerging economies are serial defaulters, so fiscal crises are recurring, rather than one-off events.

Fiscal stress facing advanced economies differs from this characterization of emerging economies along several dimensions. In most, but not all, advanced economies, fiscal stress

*February 14, 2011. Prepared for the 39th Australian Conference of Economists. We thank Huixin Bi for helpful discussions.

${ }^{\dagger}$ Indiana University, Monash University and NBER, 105 Wylie Hall, Bloomington, IN 47405; phone: (812) 855-9157; eleeper@indiana.edu.

¥Indiana University, 105 Wylie Hall, Bloomington, IN 47405; phone: (812) 856-2892; walkertb@indiana.edu.

${ }^{1}$ Sturzenegger and Zettelmeyer (2006) is an excellent recent survey of sovereign debt crises in emerging economies, while Reinhart and Rogoff (2009) provide a broader historical perspective on financial crises. 
has been a slowly evolving problem brought on by aging populations and pay-as-you-go social benefits programs for the aged. Growing promised old-age benefits, with no plans on the books to finance them, have placed fiscal projections on unsustainable trajectories. Advanced economies tend to be more diversified and, therefore, less sensitive to external disturbances, while their political systems are more stable and their fiscal infrastructures more sound. Flexible exchange rates and home currency denominated government debt open channels of adjustment to fiscal stress that are not available to emerging economies.

Table 1 reports the International Monetary Fund's (2009) calculations of the net present value of aging-related spending in several advanced economies. Averaged across the G-20 countries, spending promises exceed funding plans to the tune of 400 percent of GDP. In the United States alone, the long-term imbalance associated with Social Security and Medicare is $\$ 75$ trillion in present value [Gokhale and Smetters (2007)]. Although the Australian fiscal position is now quite healthy, sizeable unfunded liabilities lurk in the future, according to the IMF.

\begin{tabular}{lr}
\hline Country & $\begin{array}{r}\text { Aging-Related } \\
\text { Spending }\end{array}$ \\
\hline \hline Australia & 482 \\
Canada & 726 \\
France & 276 \\
Germany & 280 \\
Italy & 169 \\
Japan & 158 \\
Korea & 683 \\
Spain & 652 \\
United Kingdom & 335 \\
United States & 495 \\
Advanced G-20 Countries & 409 \\
\hline
\end{tabular}

Table 1: Net present value of impact on fiscal deficit of aging-related spending, in percent of GDP. Source: International Monetary Fund (2009).

Emerging economies do not face the fiscal stress depicted in table 1, in large part because their populations are much younger. With more young people working to support benefits to the old, the type of fiscal stress facing advanced economies does not appear on the horizon for emerging economies, as figure 1 illustrates. The figure shows how old-age dependency ratios - population aged 65 or over relative to population aged 15-64-change across time in selected advanced and emerging economies. Japan stands out as having the oldest population in 2005 and projected for 2050, with Korea, Germany, and Spain not far behind. Emerging economies have much younger populations, now and going forward, than 
do advanced economies. Because advanced economies also tend to have broader old-age programs, their older populations portend ever-increasing demands on government spending coupled with an ever-shrinking stock of young workers to support those demands. This is a recipe for fiscal stress.

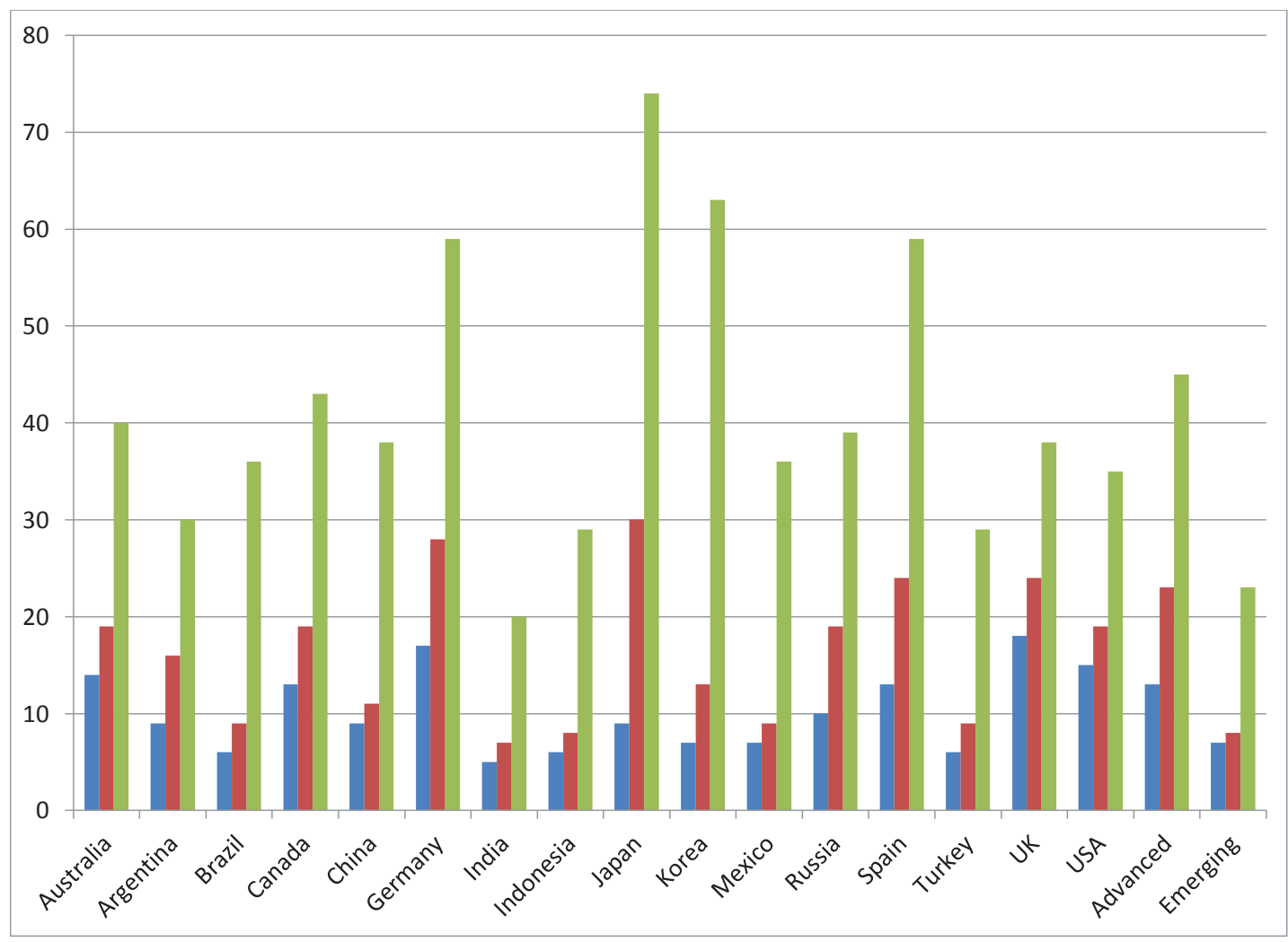

Figure 1: Population aging in advanced and emerging economies, 1960 (left bar), 2005 (center bar) and 2050 (right bar). Old-age dependency ratio, defined as population aged 65 or over relative to population aged 15-64, in percent. Source: United Nations (2008).

With emerging economies in mind, theoretical work on sovereign debt default has largely built on Eaton and Gersovitz (1981) to address the question of why creditors are willing to lend to sovereigns in the first place. Eaton and Gersovitz's key emphasis was on a sovereign's willingness to pay, rather than its ability. Another line of work treats sovereign debt default as an economic or political necessity, rather than as the outgrowth of an optimal policy problem, and derives the implications for monetary policy's ability to control inflation [Uribe (2006), Schabert (2010), and Bi, Leeper, and Leith (2010)].2

A third line of attack takes outright default off the table to examine the impacts of

\footnotetext{
${ }^{2}$ See also Juessen, Linnemann, and Schabert (2009), Bi (2009), and Bi and Leeper (2010) for non-monetary analyses.
} 
alternative fiscal and monetary policy adjustments that ensure government solvency. ${ }^{3}$ To our thinking, this line may be most pertinent to the problems facing many advanced economies with no recent history of sovereign debt default.

Ruling out default means that bondholders must expect some adjustments in future policies to occur that ensure the government continues to honor its debt obligations. Most governments have been exceedingly uninformative about which policies will adjust and when they will adjust. In the absence of credible policy plans, it is reasonable for people to contemplate the possibility that unresolved fiscal stress will push the economy to its fiscal limit - the point beyond which taxes and government expenditures can no longer adjust to stabilize the value of government debt. Macroeconomic policies can perform very differently in an economy that is staring at its fiscal limit. This paper describes how fiscal stress can affect the macro economy: first, by undermining the ability of the central bank to control inflation and influence the real economy in the usual ways; second, by injecting additional uncertainty into the economy. Beyond the literature on sovereign debt default, there is little work on how to model fiscal limits. We discuss what has been done on fiscal limits and how that work can be improved. The paper concludes by sketching a research agenda, pointing to some major unresolved theoretical and empirical issues associated with fiscal stress; there are many.

\section{Fiscal Stress, Inflation Control, and Heightened Uncertainty}

A simple model can illustrate how unresolved fiscal stress and its concomitant uncertainty about future policies undermines the central bank's ability to control inflation. ${ }^{4}$ The model emphasizes that monetary and fiscal policies have two tasks to perform - control inflation and stabilize the value of government debt - and it points to two different policy assignments that can achieve those tasks, but with very different consequences for monetary and fiscal policy effects.

2.1 A Model We now lay out a simple model that describes the link between fiscal limits and inflation. The economy lasts for $S$ periods. A representative household receives an endowment, $y$, of goods each period and chooses sequences of consumption and bonds, $\left\{c_{t}, B_{t}\right\}$, to maximize

$$
E_{0} \sum_{t=0}^{S} \beta^{t} u\left(c_{t}\right), \quad 0<\beta<1
$$

\footnotetext{
${ }^{3}$ Work taking this approach includes Cochrane (2011), Daniel and Shiamptanis (2010), Davig, Leeper, and Walker (2010, 2011), Davig and Leeper (2010), and Sims (2011).

${ }^{4}$ The points that this illustrative model make have been generalized in numerical work by [Davig, Leeper, and Walker (2010, 2011) and Davig and Leeper (2010)].
} 
subject to the budget constraint

$$
c_{t}+\frac{B_{t}}{P_{t}}+\tau_{t}=y+\lambda_{t} z_{t}+\frac{R_{t-1} B_{t-1}}{P_{t}}
$$

taking prices and $R_{-1} B_{-1}>0$ as given. The household pays taxes, $\tau_{t}$, and receives transfers, $\lambda_{t} z_{t}$, each period, both of which are lump sum. Bonds are denominated in nominal terms ("dollars") and pay a gross nominal return of $R$. The budget constraint distinguishes between the transfers that the government promises to pay, $z_{t}$, and the transfers the government actually delivers, $\lambda_{t} z_{t}$, which must ultimately be financed.

Government spending is zero each period, so the government chooses sequences of taxes, delivered transfers, and debt to satisfy its flow constraint

$$
\frac{B_{t}}{P_{t}}+\tau_{t}=\lambda_{t} z_{t}+\frac{R_{t-1} B_{t-1}}{P_{t}}
$$

given $R_{-1} B_{-1}>0$, while the monetary authority chooses a sequence for the nominal interest rate.

After imposing goods market clearing, $c_{t}=y$ for $t \geq 0$, the household's consumption Euler equation reduces to the simple Fisher relation

$$
\frac{1}{R_{t}}=\beta E_{t}\left(\frac{P_{t}}{P_{t+1}}\right)
$$

The exogenous (fixed) gross real interest rate, $1 / \beta$, makes the analysis easier but is not without some loss of generality, as Davig, Leeper, and Walker (2010) show in the context of fiscal financing in a model with nominal rigidities.

2.2 Policy Behavior Monetary policy follows a conventional interest rate rule, written in terms of the inverse of the nominal interest and inflation rates

$$
R_{t}^{-1}=R^{*-1}+\alpha\left(\frac{P_{t-1}}{P_{t}}-\frac{1}{\pi^{*}}\right)
$$

where $\pi^{*}$ is the inflation target and $R^{*}=\pi^{*} / \beta$ is the steady state nominal interest rate. When $\alpha>1 / \beta$ monetary policy is hawkish, responding to increases in inflation by sharply raising the nominal interest rate with the aim of stabilizing inflation around $\pi^{*}$. This is called "active" monetary policy. Weak responses of interest rates to inflation are called "passive" monetary policy. 
Fiscal policy adjusts taxes in response to the state of government debt

$$
\tau_{t}=\tau^{*}+\gamma\left(\frac{B_{t-1}}{P_{t-1}}-b^{*}\right)
$$

where $b^{*}$ is the debt target, $\tau^{*}$ is the steady state level of taxes, and $r=1 / \beta-1$ is the net real interest rate. When $\gamma>r$ any increase in government debt creates an expectation that future taxes will rise by enough to both service the higher debt and retire it back to $b^{*}$. This is called "passive" fiscal policy. Weak responses of taxes to debt correspond to "active" fiscal policy.

We assume that "promised" government transfers evolve exogenously according to the stochastic process

$$
z_{t}=(1-\rho) z^{*}+\rho z_{t-1}+\varepsilon_{t}, \quad 0<\rho<1
$$

where $z^{*}$ is steady-state transfers and $\varepsilon_{t}$ is a serially uncorrelated shock with $E_{t} \varepsilon_{t+1}=0$.

Most macroeconomic models contain no uncertainty about future policy regimes, making the implausible assumption that agents know exactly what monetary and fiscal policies will be in effect at every date in the future. Although this assumption is widely maintained, it is difficult to reconcile the assumption with observed policy behavior. In fact, policies do change and, therefore, they can change. In the face of a history of changes in policy regimes, analyses that fail to incorporate the possibility of regime change into expectations formation run the risk of misspecifying expectations and providing misleading policy advice. ${ }^{5}$ Given the prominent role ascribed to expectations formation in policy discussions and deliberations, this is a potentially serious misspecification of policy models.

We introduce uncertainty about policy in a stark fashion that allows us to extract some implications of policy uncertainty while retaining analytical tractability. The economy hits the fiscal limit at a known date $T$, at which point taxes become active, no longer responding to stabilize debt. At the fiscal limit, taxes are fixed: $\tau_{t}=\tau^{\max }$ for all $t \geq T$. Uncertainty arises because agents are uncertain which policy regime will be adopted at the fiscal limit. Agents place probability $q$ on a regime that combines passive monetary policy with active transfers policy. Active transfers means that promised transfers are delivered and $\lambda_{t}=1$. In this regime, neither taxes nor transfers can adjust to stabilize debt, so monetary policy takes on the role of stabilizing debt.

Agents place probability $1-q$ on a regime with active monetary policy and passive transfers policy. In polite company, passive transfers policy is referred to as "entitlements

\footnotetext{
${ }^{5}$ This is the theme of Cooley, LeRoy, and Raymon (1982, 1984), Sims (1982, 1987), Andolfatto and Gomme (2003), Leeper and Zha (2003), Davig (2004), Davig and Leeper (2006b,a, 2007, 2011), Chung, Davig, and Leeper (2007), and Davig, Leeper, and Walker (2010).
} 
reform." To avoid the tangle of euphemisms, we refer to this as "reneging on promised transfers." Instead of receiving promised transfers of $z_{t}$ at time $t$, agents receive $\lambda_{t} z_{t}\left[\lambda_{t} \in\right.$ $(0,1)]$, a fraction of promised transfers that the government honors. That fraction adjusts as needed to stabilize debt. Because monetary policy continues to aggressively target inflation, once the economy enters this regime, inflation will always be on target: $\pi_{t}=\pi^{*}$ for $t \geq T$.

For simplicity, we reduce the model to just four periods. In the initial two periods $(t=0,1)$, the fiscal limit has not been reached, promised transfers follow the process in $(7)$, monetary policy is active and tax policy is passive. The economy begins with $R_{-1} B_{-1}>0$ given and some arbitrary $P_{-1}$. At the beginning of period two $(t=2)$, the fiscal limit is reached but agents remain uncertain about which mix of policies will be adopted. This uncertainty is resolved at the end of period 2, so that in period 3 there is no uncertainty about policy.

2.3 Equilibrium Combining the Fisher relation, (4), with the active monetary policy rule, (5), for periods 0 and 1 yields

$$
E_{0}\left(\frac{P_{1}}{P_{2}}-\frac{1}{\pi^{*}}\right)=\frac{\alpha^{2}}{\beta^{2}}\left(\frac{P_{-1}}{P_{0}}-\frac{1}{\pi^{*}}\right)
$$

and combining the government budget constraint, (3), with the passive tax rule, (6), yields

$$
E_{0}\left(\frac{B_{1}}{P_{1}}-b^{*}\right)=E_{0}\left(z_{1}-z^{*}\right)+\left(\beta^{-1}-\gamma\right)\left(\frac{B_{0}}{P_{0}}-b^{*}\right)
$$

Agents know that in the next period $(t=2)$ the fiscal limit will be reached and policy will switch to either a passive monetary/active transfers regime with probability $q$, or an active monetary/passive transfers regime with probability $(1-q)$. Assume that the reneging rate is fixed and known at $t=0$, so $\lambda_{2}=\lambda_{3}=\lambda \in[0,1]$. Then the conditional probability distribution of these policies is given by

$$
\begin{array}{rcl}
\text { Probability } & \text { Monetary Policy } & \text { Transfers Policy } \\
q & R_{2}^{-1}=R^{*-1} & z_{2}=\rho z_{1}+\varepsilon_{2} \\
(1-q) & R_{2}^{-1}=R^{*-1}+\alpha\left(\frac{P_{1}}{P_{2}}-\frac{1}{\pi^{*}}\right) & \lambda z_{2}=\lambda \rho z_{1}+\lambda \varepsilon_{2}
\end{array}
$$


The analogs of (8) and (9) for period 2 are

$$
\begin{gathered}
E_{2}\left(\frac{P_{2}}{P_{3}}-\frac{1}{\pi^{*}}\right)=(1-q) \frac{\alpha}{\beta}\left(\frac{P_{1}}{P_{2}}-\frac{1}{\pi^{*}}\right) \\
E_{1}\left(\frac{B_{2}}{P_{2}}-b^{*}\right)=[q+(1-q) \lambda] E_{1} z_{2}-z^{*}+\beta^{-1}\left(\frac{B_{1}}{P_{1}}-b^{*}\right)
\end{gathered}
$$

In (11) we have imposed that $\tau^{\max }=\tau^{*}$, the steady state level of taxes, in order to make the relationships transparent.

In period $3, \tau_{3}$ is set to completely retire debt $\left(B_{3}=0\right)$ no matter which policy regime is realized in period 2. This corresponds to $\tau_{3}=\delta z_{3}+\left(R_{2} B_{2}\right) / P_{3}$, where $\delta=1$ if the economy is in the passive monetary/active transfers regime and $\delta=\lambda$ if the active monetary/passive transfer regime is realized. This assumption implies that agents know one period in advance which tax policy will be in place in the final period.

Combining (8) and (10), we obtain a relationship that connects expected inflation between periods 2 and 3 to actual inflation in the initial period

$$
E_{0}\left(\frac{P_{2}}{P_{3}}-\frac{1}{\pi^{*}}\right)=(1-q) \frac{\alpha^{3}}{\beta^{3}}\left(\frac{P_{-1}}{P_{0}}-\frac{1}{\pi^{*}}\right)
$$

Given the discount rate $\beta$, this solution for expected inflation shows that whether expected inflation converges to target or drifts from target depends on the probability of switching to passive monetary/active transfers policies relative to how hawkishly monetary policy targets inflation when it is active.

Since we assume that taxes in period 3 are known, and they are a function of exogenous objects, we can treat $\tau_{3}$ as fixed. Combining (9) and (11) and imposing that $B_{3}=0$ as the debt target in the last period

$$
\frac{B_{0}}{P_{0}}-b^{*}=\left(\frac{1}{\beta^{-1}-\gamma}\right) E_{0}\left\{\beta^{2}\left[\left(\tau_{3}-\tau^{*}\right)-\left(\vartheta z_{3}-z^{*}\right)\right]-\beta\left(\vartheta z_{2}-z^{*}\right)-\left(z_{1}-z^{*}\right)\right\}
$$

where $\vartheta=q+(1-q) \lambda$ determines expected post-reneging transfers.

Because all the objects on the right side of (13) are known or exogenous, this expression uniquely determines the value of debt in period 0 as a function of the expected present value of surpluses. We can combine (13) with the government's flow constraint at $t=0$ to obtain a unique expression for $P_{0}$ as a function of $R_{-1} B_{-1}, \tau_{0}, z_{0}$, and the parameters in the expression for equilibrium $B_{0} / P_{0}$.

2.4 Implications Solutions (12) and (13), together with the government's budget constraint, yield the equilibrium price level, expected inflation, and nominal debt at the initial 
date, $t=0$. The solutions encapsulate the sense in which monetary policy loses control of inflation if fiscal expectations are not appropriately anchored. We can now summarize the implications:

1. Monetary policy can consistently achieve its inflation target, $\pi_{t}=\pi^{*}$, only if fiscal expectations are anchored on policies in which debt is stabilized entirely by fiscal adjustments. In this model, such anchoring requires that $q=0$, so there is no possibility of a regime in which monetary policy becomes passive $(0 \leq \alpha<1 / \beta)$ and transfers policy is active, with promised transfers being fully honored $(\lambda=1)$.

2. If people deem the passive monetary/active transfers regime to be possible, $q>0$, then expressions (12) and (13) guide the determination of actual and expected inflation, yielding some striking results.

(a) For a given $q>0$, the more hawkish is monetary policy, the more decoupled expected inflation is from past inflation: in (12), larger $\alpha$ makes deviations of expected inflation from target drift farther from deviations of actual inflation from target.

(b) As the probability of the passive monetary/active transfers regime, $q$, rises, expected inflation departs less from actual inflation; in fact, as $q \rightarrow 1$, expected inflation converges to $\pi^{*}$.

(c) Higher $q$ reduces the value of debt in expression (13), which raises the initial price level, $P_{0}$.

(d) The smaller the rate of reneging on transfers, $\lambda$, the lower the value of debt and the higher the price level $P_{0}$.

Higher $q$ and lower $\lambda$ raise inflation through the standard fiscal theory of the price level mechanisms. ${ }^{6}$ Higher $q$ means there is less likelihood that the government will renege, so expected transfers and, therefore, household wealth rise. Households attempt to convert the higher wealth into consumption goods, driving up the price level until real wealth falls sufficiently that households are content to consume their original consumption place. Lower $\lambda$ also raises the expected value of transfers, increasing wealth and raising the price level through the same channels.

Expectational effects associated with switching policies can be seen explicitly in (12) and (13). Equation (13) shows that the value of debt is still determined by the discounted

\footnotetext{
${ }^{6}$ See, for example, Leeper (1991), Sims (1994), Woodford (2001), or Walsh (2003) for expositions of the fiscal theory.
} 
expected value of net surpluses. In contrast to models without uncertainty about future policies, now the actual surplus is conditional on the realized policy regime. Conditional on time $t=0$ information, the expected transfers process in periods 2 and 3 is unknown. If $q \in(0,1)$ and at the end of period two passive monetary policy is realized, agents will be "surprised" by amount $z_{2}(1-q)(1-\lambda)$ in period 2 and by amount $z_{3}(1-q)(1-\lambda)$ in period 3. With transfers surprisingly high - because the passive transfers regime with reneging was not realized-households feel wealthier and try to convert that wealth into consumption. This drives up the price level in periods 2 and 3, revaluing debt downward. This surprise acts as an innovation to the agent's information set due to policy uncertainty. Naturally, as agents put high probability on this regime occurring $(q \approx 1)$ or assume the amount of reneging is small $\left(\lambda_{2}, \lambda_{3} \approx 1\right)$, the surprise is also small, and vice versa.

Expected inflation in period 1 now depends on $q$, which summarizes beliefs about future policies. But $q$ is a parameter of both monetary and transfers policy. This illustrates that monetary policy alone cannot determine either actual or expected inflation. If agents put high probability on the passive monetary/active transfers regime $(q \approx 1)$, then expected inflation at the beginning of period 2 will be primarily pinned down by the nominal interest rate peg. It is in this sense that expectational effects about policy uncertainty can dramatically alter equilibrium outcomes.

In this simple setup, these expectational effects are limited in magnitude because agents know precisely when the fiscal limit is reached. The additional level of uncertainty not examined in these simple models, but present in Davig, Leeper, and Walker (2010), is randomness about when tax policy will hit the the fiscal limit. In that environment, the conditional probability of switching policies outlined above would contain an additional term specifying the conditional probability of hitting the fiscal limit in that period. This implies that, because there is positive probability of hitting the fiscal limit in every period up to $T$, these expectational effects will be present from $t=0, \ldots, T$ and will gradually become more prominent as the probability of hitting the fiscal limit increases. In effect, the endogenous probability of hitting the fiscal limit makes the probability $q$ time varying.

The illustrative model places in high relief a general lesson for policymakers: unresolved fiscal stress can undermine the ability of monetary policy to control inflation, regardless of how devoutly the central bank targets inflation. Loss of inflation control arises for fiscal reasons that are beyond the purview of the central bank. More aggressive inflation targeting cannot compensate for inappropriately anchored fiscal expectations. 


\section{Modeling Fiscal Limits}

Although there is little doubt that every country possesses a fiscal limit, we are very far from understanding how to quantify that limit. Once more setting aside sovereign debt default as a type of fiscal limit, there are at least three categories of limits that arise in the literature.

Sargent and Wallace (1981) invoke that the public's desired level of savings imposes an upper bound on the equilibrium debt-GDP ratio that can be attained. Their economy starts in a regime where both monetary and fiscal policy are active - money growth and the primary fiscal surplus are exogenous processes - and government debt accumulates to cover any budget shortfalls. When debt reaches its upper bound, Sargent and Wallace posit that monetary policy switches to passively generate the seigniorage revenues required to stabilize debt at that fiscal limit.

The notion that the debt-GDP ratio must be bounded is closely related to the second category of fiscal limits: higher distorting taxes diminish incentives to work, save, and invest, so there is some set of tax rates that maximize tax revenue and place the economy at the peak of its Laffer curves. ${ }^{7}$ Holding government expenditures fixed, maximum tax revenues imply some maximum stream of primary surpluses. Because government debt derives its value from the expected present value of primary surpluses plus seigniorage revenues, and that present value is bounded, so, too, is the size of government debt relative to the economy. Tax distortions, therefore, create a natural fiscal limit by imposing a limit on the "cash flows" that support government debt.

Although it provides a natural economic fiscal limit, Laffer curve reasoning fails to bring in political economy arguments that are more likely to determine fiscal limits in democratic societies. Top all-in marginal tax rates vary tremendously across advanced economies: from 38 percent in New Zealand to 63 percent in Denmark, and averaging about 48 percent. $^{8}$ Trabandt and Uhlig (2009) estimate that, with only a couple of exceptions, average labor, capital, and consumption tax rates in 14 European Union countries and the United States lie below the peak of their respective Laffer curves and, frequently, well below the peak. By revealed preferences, even countries that face fiscal stress are reluctant to push tax rates to the point where revenue is maximized.

We believe that both economic and political factors weigh heavily in the fiscal limit

\footnotetext{
${ }^{7}$ Some authors have studied equilibria in which debt is not bounded in order to argue that monetarist/Ricardian equilibria are, in some sense, "general" [McCallum (1984) and Canzoneri, Cumby, and Diba (2001)]. Those equilibria fall apart, however, under the plausible assumption that the government does not have unlimited access to non-distorting taxes.

${ }^{8}$ Statistics based on the marginal combined personal income tax rate on gross wage income (derived according to the OECD Taxing Wages framework) for a single person without dependants based on the earnings level where the top statutory rate first applies, combined central and sub-central governments [Organization for Economic Co-operation and Development (2009)].
} 
calculus. Political intolerance of high and rising marginal tax rates is likely to place an effective upper bound on rates well before reaching the peak of the Laffer curve. Major tax reforms in the United States, the United Kingdom, Sweden, and elsewhere in the 1980s and 1990s, which dramatically lowered marginal tax rates across the board, were brought on by demands by the electorate for smaller government or reduced inefficiencies. That political consensus continues to reign even as populations age and fiscal stresses grow.

Several papers take a reduced-form approach to modeling political intolerance for rising marginal tax rates [Davig, Leeper, and Walker (2010, 2011), Davig and Leeper (2010), and Richter (2011)]. Those papers posit that, as in the simple model above, there is a regime in which higher debt is financed by higher marginal tax rates. But as tax rates increase, political dissatisfaction rises. An increasingly disgruntled electorate raises the probability that the economy will hit its fiscal limit, at which point tax rates can no longer rise. Figure 2 illustrates the logistic function those papers employ to characterize how the probability of the limit increases with the tax rate.

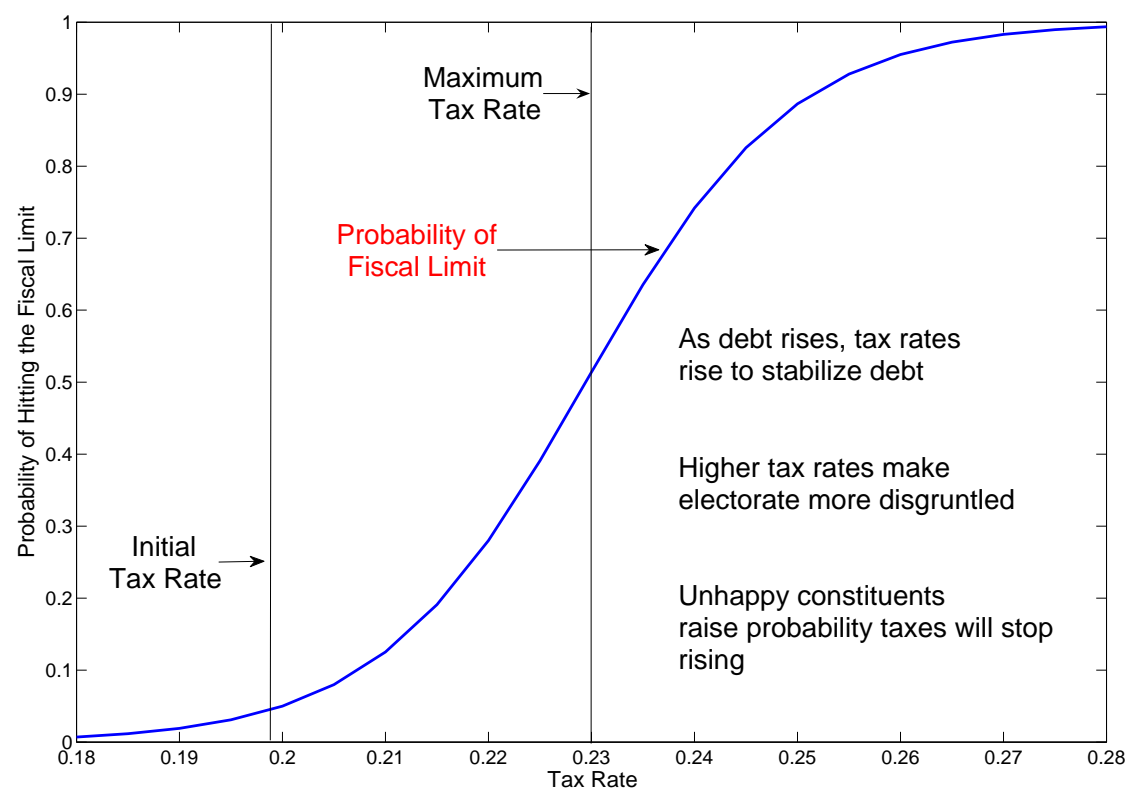

Figure 2: Probability of hitting the fiscal limit - a fixed maximum marginal tax rate - as a function of the tax rate. Source: Davig, Leeper, and Walker (2010).

This reduced-form approach has the virtue of treating the fiscal limit as uncertain, yet dependent on the state of fiscal policy. But it also has important shortcomings. First, there is no microeconomic rationale for using a logistic function to describe how the probability of hitting the limit evolves over time. Second, it is not obvious how best to connect the 
parameters of the fiscal limit function to observed data. Third, by taking a reduced-form approach, the method does not attempt to model any of the political or economic factors that determine the fiscal limit. Finally, as figure 2 makes clear, the limit is couched only in terms of tax adjustments; social attitudes toward the government's provision of goods and services play an equally important role in fiscal adjustments.

Understanding what factors influence a society's attitudes toward taxation and government spending is essential to understand the consequences of fiscal stress. We turn now to suggestions for future research that will contribute to that understanding.

\section{A Research Agenda}

A country's fiscal limit depends not only on the current fiscal situation but also on expected future surpluses and is therefore, unobservable. For this reason, there are many subtle aspects to understanding and modeling fiscal limits in advanced economies. This section focuses on four elements of fiscal limits that we believe are important for future research: [i] identifying policy behavior; [ii] quantifying fiscal limits; [iii] integrating heterogeneity and policy uncertainty; [iv] anchoring fiscal expectations appropriately so that monetary policy can control inflation. These elements are obviously interrelated. Quantifying fiscal limits requires an accurate depiction of policy behavior, which depends on modeling the political economy, and so forth. The list is not exhaustive, but represents our views about the most important omissions in our own work and in the current literature.

4.1 Identifying Policy Behavior Leeper (2010) argues that conducting fiscal policy analysis is much more challenging than monetary policy analysis due to "fiscal complexity." Relative to monetary policy, fiscal policy makers have an ever-expanding range of fiscal instruments at their disposal - a complex tax code, a range of government spending decisions, debt maturity structure, and so forth. And the ability to legislate implies entirely new fiscal instruments can be created to deal with fiscal stress. All of these fiscal instruments will have an impact on a country's fiscal limit. In light of this complexity, modeling or identifying fiscal policy behavior can be quite challenging. But because these fiscal changes distort important economic margins, an accurate depiction of (future) policy behavior is critical to modeling fiscal limits.

Advanced economies have sophisticated political economy structures underlying their fiscal policies. Modeling fiscal policy using simple rules or as a benevolent social planner (or malevolent dictator), as is often done, seems inappropriate. Replacing the logistic curve of figure 2 with a coherent political economy structure would advance the literature.

Recent work in political economy incorporates intricate policy formulations into a dy- 
namic, stochastic, equilibrium framework [for example, Battaglini and Coate (2008)]. Entitlements reform is an example. As outlined in section 2.2, which draws on the work by Davig, Leeper, and Walker (2010, 2011) and Davig and Leeper (2010), entitlements reform or "reneging" on promised transfers enters the model through a reduced form parameter $\lambda$, the fraction of promised transfers that is delivered. Calibrating $\lambda$ is quite difficult without linking it explicitly to the political economy. Many citizens view promised old-age benefits as a social contract whose violation has wide-ranging repercussions for the relationship between the electorate and its government. Here there is an inherent tension: fiscal stress is arising from aging populations, but it is the same bulge in the population that is being asked to sacrifice through entitlements reform - will the old vote to make themselves less well off? Capturing these delicate relationships through a political economy setup would be a welcome addition to the literature.

It is not feasible to capture every dimension of fiscal policy in identifying policy behavior. To understand fiscal limits, it might be more important to identify specific characteristics of policy formation. For example, policy stickiness suggests that advanced economies with well-developed democratic institutions may not be able to act quickly enough to mitigate the deleterious effects of fiscal limits [Alesina and Drazen (1991)]. Stickiness is an outgrowth of the checks and balances of a democratic society, "by which the excellences of republican government may be retained and its imperfections lessened or avoided," as Hamilton (1787) wrote. But policy stickiness may also hasten the arrival of a fiscal limit by delaying the policy responses that would keep the economy away from the limit. Auerbach and Hassett (1992, 2001, 2002) and Hassett and Metcalf (1999) show that policy stickiness dramatically affects investment and consumption decisions in a standard dynamic stochastic overlapping generations model. Auerbach and Hassett (2007) find that policy stickiness dramatically changes the nature of the equilibrium and of optimal policy. These results would be amplified in an environment with a looming fiscal limit.

4.2 Quantifying Fiscal Limits How close is a country to its fiscal limit? This question is central to articulating the options available to policy makers and to understanding the economic ramifications of a fiscal limit. But there is a dearth of research on the question. Quantifying the fiscal limit is challenging for reasons of fiscal complexity and because it relies on taking stands on unknown policy outcomes. There may be ways, though, to estimate a country's fiscal limit. For example, one policy option is to raise taxes to continue to fund old-age benefits until tax revenues decline; that is, until the peak of the Laffer curve is reached. Countries that are currently close to the peak of the Laffer curve will hit the fiscal limit sooner than those with room to raise taxes and increase revenue. 
Recent work by Trabandt and Uhlig (2009) attempts to estimate Laffer curves for several countries. They document tremendous diversity in tax rates (and tax structures) across advanced countries. In 2007 the highest labor income tax rate was in Sweden (54.6 percent) and the lowest was in the United States (28.4 percent); for capital tax rates, the highest was in Denmark (59.3 percent) and the lowest was in Greece (14.5 percent); the United States had the lowest consumption tax rate by far (4.2 percent), while Denmark had the highest (34.3 percent). Using estimates from a stochastic growth model, Trabandt and Uhlig find similar heterogeneity with regard to where countries lie on their Laffer curves. They claim that some countries are already operating on the wrong side of the Laffer curve, while others have a substantial buffer before hitting the peak of the Laffer curve. Coupled with the fact that many advanced economies have dramatically different government spending programs, tax diversity suggests that a one-size-fits-all approach to quantifying fiscal limits would be unproductive. Many pundits (and academics) cite the debt-to-GDP ratio as a measure of fiscal stress. Trabandt and Uhlig's results argue for more subtlety. For example, suppose two countries have identical debt-to-GDP ratios but country A is operating on the wrong side of the Laffer curve, while country B still has the ability to raise tax revenues. Surely, country B is much further away from its fiscal limit. ${ }^{9}$

There is a clear need to take models of fiscal policy to data as Trabandt and Uhlig (2009) have done. But the fiscal stress facing advanced economies is unprecedented, which raises the question: how can we extrapolate from past data to better quantify the fiscal limit? While the United States and several other countries have encountered some form of fiscal stress in past decades, this time is different. At no point in the history of the United States (or other advanced economies) have we had the demographic trends playing out today. These are important limitations to the data that must be overcome through solid theoretical foundations. However, just as we should not rely solely on data that have no relevant observations, we also should not throw out all data and rely only on theoretical constructs.

We offer two examples of how data might be able to enhance our understanding of fiscal stress and fiscal limits. First, while there are few relevant data points to quantify fiscal limits in advanced economies, there are some projections that are likely to be quite accurate. These projections could be inserted into general equilibrium models as a way to simulate data points. For example, demographic projections over the next 20 to 50 years will be accurate (barring some unforeseen catastrophe). While we are unsure of how fiscal policy will respond

\footnotetext{
${ }^{9}$ Ghosh, Kim, Mendoza, Ostry, and Qureshi (2011) use data for 23 advanced economies from 1970-2007 and to conclude that fiscal limits vary substantially across advanced economies. Bi (2009) documents the wide range of debt-GDP ratios at which countries run into sovereign debt problems.
} 
to aging baby boomers, we are relatively confident that projections of old-age dependency ratios, like those in figure 1 , will come to fruition. These demographic changes would be the driving processes in a political economy model that examines alternative policy responses to fiscal stress. In a similar fashion, Davig, Leeper, and Walker (2010) use Congressional Budget Office projections of the growth in entitlements programs over the next 60 years to calibrate a nonstationary transfers process. Although it is debatable whether promised entitlements will actually be paid in the future, it is hard to argue that the CBO is grossly miscalculating the trend growth rate in these spending programs.

A second example involves a recent occurrence in American politics to combat fiscal pressures. In times of fiscal stress, proposals to amend the U.S. constitution to require the federal government to operate under a balanced budget rule gain currency. Calls for a balanced budget amendment became particularly strident in the 1980s and 1990s. An amendment requiring a balanced budget was nearly passed in 1995: the House of Representative approved the amendment by 300 to 132 but it fell one vote short in the Senate. More recently, Senators Lindsay Graham and Jim DeMint introduced a balanced budget amendment last year (SJ Res 24), which is still in committee. As fiscal pressures increase, this type of policy reaction becomes increasingly likely. Although this empirical observation does not provide a clear indication of how to model fiscal policy, it does suggest the importance of building in the possibility of adopting a policy rule that incorporates a balanced budget.

4.3 Combining Heterogeneity with Policy Uncertainty There is a large and compelling literature that focuses on important intergenerational and distributional consequences of fiscal stress and fiscal limits [for example, Auerbach and Kotlikoff (1987), Kotlikoff, Smetters, and Walliser (1998a,b, 2007), İmrohoroğlu, İmrohoroğlu, and Joines (1995, 1999), Huggett and Ventura (1999), Cooley and Soares (1999), De Nardi, İmrohoroğlu, and Sargent (1999), Altig, Auerbach, Kotlikoff, Smetters, and Walliser (2001), and Smetters and Walliser (2004)]. The canonical model used in these papers is an overlapping generations model in which each cohort lives for 55 periods. This model permits rich dynamics in demographicspopulation-age distributions, increasing longevity - intra-generational heterogeneity, bequest motives, liquidity constraints, earnings uncertainty, and so forth; it also allows for flexibility in modeling fiscal variables and alternative policy scenarios. The literature emphasizes that heterogeneity in demographics and policy are first order when considering how fiscal policy affects welfare. The richness and complexity of the models, though, mean that only perfect foresight equilibria (or slight deviations from perfect foresight) are computed. The forward looking nature of the equilibrium pushes nearly all of the effects of fiscal stress into the present, which places unrealistically high weight on gloom-and-doom outcomes that are 
difficult to reconcile with observed data.

Papers by Davig, Leeper and Walker focus on modeling policy uncertainty and the complex interactions between fiscal and monetary policies. Their shortcoming is that the analysis is carried out in a representative agent environment that does not address the important distributional effects of fiscal policy.

A synthesis of these two approaches is essential for effectively modeling fiscal limits. Ignoring heterogeneity ignores the root cause of the problem. Demographics are driving the economy closer to the fiscal limit. But ignoring policy uncertainty assumes agents know far too much about pending policy adjustments. While acknowledging the need to act, politicians have done very little to inform their constituents about which policies will adjust and when.

Capturing both heterogeneity and substantial policy uncertainty in a dynamic, stochastic general equilibrium model is challenging. Nonlinear methods, which come with steep computational costs, must be employed. Recent work by Richter (2011) is an example of a model that captures both elements. He introduces a nonstationary promised entitlements process into the infinite period OLG setup of Yaari (1965) and Blanchard (1985). The primary benefit of his setup vis-a-vis traditional OLG frameworks is the ability to examine the distributional consequences of fiscal uncertainty. The flexibility of the model permits a regime-switching approach to policy uncertainty along with an OLG framework to address distributional effects. Preliminary results suggest that the distributional consequences of policy uncertainty are substantial. These findings are intriguing and further work along these lines is needed.

\subsection{Anchoring Fiscal Expectations and Non-Rational Expectations As the} simple model in section 2.2 makes clear, anchoring fiscal expectations in the appropriate way is essential for monetary policy to control inflation. Once taxes have reached the fiscal limit, there are only two possible sources of fiscal financing: [i] reneging on promised transfers and [ii] surprise revaluations of outstanding nominal government bonds. Only under case [i] does an active monetary policy rule - such as the Taylor rule - continue to control inflation.

In a rational expectations environment, if agents place positive probability on scenario [ii] (even if it is not realized), monetary policy loses control of inflation. As scenario [ii] becomes more (less) likely, the actions of the monetary authority become more (less) futile. These powerful expectational effects are precisely what undermines "sound" fiscal policy.

But is a rational expectations framework appropriate in an environment where agents have almost no guidance from their government about how the fiscal stress will be resolved? Given that policy uncertainty must be cleanly modeled in a rational expectations 
framework - that is, agents' subjective probability distributions must coincide with actual probability distributions - a non-rational expectations framework may be better suited to address questions of anchoring expectations. If agents have substantial uncertainty over which regime will materialize, allowing for subjective distributions to be robust to alternative policy scenarios seems reasonable.

We mention two examples of work that examines fiscal policy uncertainty and deviates from the rational expectations paradigm. First, Eusepi and Preston (2010a,b) use a learning environment to give the notion of "anchoring fiscal expectations" precise content. They show that learning dynamics restricts the set of equilibria, relative to the rational expectations framework, in a model with uncertainty about monetary and fiscal policy. A key result is that the advantages of anchoring monetary policy are greatly diminished if fiscal expectations are not equally anchored. Agents must learn about stabilization policies in both fiscal and monetary policy simultaneously. A stable, learnable monetary policy rule is not effective without a "passive" and learnable fiscal policy rule.

Second, Karantounias, Hansen, and Sargent (2009) introduce model uncertainty into the optimal fiscal policy problem of Lucas and Stokey (1983), and find that "expectations management" plays an important role that is absent from a rational expectations framework. A social planner has a novel incentive to smooth the shadow value of the agents' subjective beliefs concerning government debt. Hence, optimal policy requires an anchoring of subjective fiscal expectations.

In describing the uncertainty surrounding fiscal policy, Sargent (2006) replaces the usual probability triple with a series of question marks. Entering an era of prolonged fiscal stress suggests that the level of uncertainty will only increase. Perhaps deviating from the rational expectations paradigm is necessary to capture this form of Knightian uncertainty.

\section{Concluding Remarks}

We have argued that there are striking parallels between monetary and fiscal policies in terms of controlling inflation, affecting the real economy, and stabilizing the value of government debt. It is strange, therefore, that most macroeconomic research focuses on one policy alone, to the exclusion of the other policy. This artificial dichotomy runs the risk of providing misleading or incomplete understandings of how unresolved fiscal stress affects the economy and how alternative resolutions to the stress will play out.

Our call for research on fiscal stress carries an urgency not often present in academic work. Policy decisions will be made, even in a research void. The time to fill that void is now. 


\section{REFERENCES}

Alesina, A., And A. Drazen (1991): "Why are Stabilizations Delayed?," The American Economic Review, 81(5), 1170-1188.

Altig, D., A. J. Auerbach, L. J. Kotlikoff, K. Smetters, and J. Walliser (2001): "Simulating Fundamental Tax Reform in the United States," American Economic Review, 91(3), 574-595.

Andolfatto, D., And P. Gomme (2003): "Monetary Policy Regimes and Beliefs," International Economic Review, 44(1), 1-30.

Auerbach, A. J., and K. Hassett (1992): "Tax Policy and Business Fixed Investment in the United States," Journal of Public Economics, 47, 141-170.

(2001): "Uncertainty and the Design of Long-Run Fiscal Policy," in Demographic Change and Fiscal Policy, ed. by A. J. Auerbach, and R. D. Lee, pp. 73-92. Cambridge University Press, Cambridge, UK.

— (2002): "Fiscal Policy and Uncertainty," International Finance, 5(2), 229-249.

(2007): "Optimal Long-Run Fiscal Policy: Constraints, Preferences, and the Resolution of Uncertainty," Journal of Economic Dynamics and Control, 31(5), 1451-1472.

Auerbach, A. J., And L. J. Kotlikoff (1987): Dynamic Fiscal Policy. Cambridge University Press, Cambridge, M.A.

Battaglini, M., and S. Coate (2008): "A Dynamic Theory of Public Spending, Taxation, and Debt," American Economic Review, 98(1), 201-236.

Bı, H. (2009): "Sovereign Risk Premia, Fiscal Limits and Fiscal Policy," Manuscript, Indiana University.

Bi, H., And E. M. Leeper (2010): "Sovereign Debt Risk Premia and Fiscal Policy in Sweden," NBEResearch Working Paper No. 15810, March.

Bi, H., E. M. Leeper, And C. Leith (2010): "Stabilization versus Sustainability: Macroeconomic Policy Tradeoffs," Manuscript, Indiana University.

Blanchard, O. J. (1985): "Debts, Deficits, and Finite Horizons," Journal of Political Economy, 93(2), 223-247. 
Canzoneri, M. B., R. E. Cumby, and B. T. Diba (2001): "Is the Price Level Determined by the Needs of Fiscal Solvency?," American Economic Review, 91(5), 1221-1238.

Chung, H., T. Davig, and E. M. Leeper (2007): "Monetary and Fiscal Policy Switching," Journal of Money, Credit and Banking, 39(4), 809-842.

Cochrane, J. H. (2011): "Understanding Policy in the Great Recession: Some Unpleasant Fiscal Arithmetic," European Economic Review, 55(1), 2-30.

Cooley, T. F., S. F. LeRoy, and N. Raymon (1982): "Modeling Policy Interventions," Manuscript, University of California Santa Barbara.

- (1984): "Econometric Policy Evaluation: Note," American Economic Review, 74(3), $467-470$.

Cooley, T. F., And J. Soares (1999): "A Positive Theory of Social Security Based on Reputation," Journal of Political Economy, 107(1), 135-160.

Daniel, B. C., And C. Shiamptanis (2010): "Fiscal Policy in the European Monetary Union," Manuscript, SUNY Albany.

Davig, T. (2004): "Regime-Switching Debt and Taxation," Journal of Monetary Economics, 51(4), 837-859.

Davig, T., And E. M. Leeper (2006a): "Endogenous Monetary Policy Regime Change," in NBER International Seminar on Macroeconomics 2006, ed. by L. Reichlin, and K. D. West, pp. 345-377. MIT Press, Cambridge, MA.

- (2006b): "Fluctuating Macro Policies and the Fiscal Theory," in NBER Macroeconomics Annual 2006, ed. by D. Acemoglu, K. Rogoff, and M. Woodford, vol. 21, pp. 247-298. MIT Press, Cambridge.

- (2007): "Generalizing the Taylor Principle," American Economic Review, 97(3), 607-635.

(2010): "Temporarily Unstable Government Debt and Inflation," Manuscript, Indiana University, October.

- (2011): "Monetary-Fiscal Policy Interactions and Fiscal Stimulus," European Economic Review, 55(2), 211-227.

Davig, T., E. M. Leeper, and T. B. Walker (2010): “Unfunded Liabilities' and Uncertain Fiscal Financing," Journal of Monetary Economics, 57(5), 600-619. 
(2011): "Inflation and the Fiscal Limit," European Economic Review, 55(1), 31-47.

De Nardi, M., S. İmrohoroĞLu, and T. J. Sargent (1999): "Projected U.S. Demographics and Social Security," Review of Economic Dynamics, 2(July), 575-615.

Eaton, J., and M. Gersovitz (1981): "Debt with Potential Repudiation: Theoretical and Empirical Analysis," Review of Economic Studies, 48(2), 289-309.

Eusepi, S., And B. Preston (2010a): "Debt, Policy Uncertainty and Expectations Stabilization," Forthcoming in Journal of the European Economic Association.

- (2010b): "The Maturity Structure of Debt, Monetary Policy and Expectations Stabilization," Manuscript, Columbia University.

Ghosh, A., J. I. Kim, E. G. Mendoza, J. D. Ostry, and M. S. Qureshi (2011): "Fiscal Fatigue, Fiscal Space and Debt Sustainability in Advanced Economies," NBER Working Paper No. 16782, February.

Gokhale, J., and K. Smetters (2007): "Do the Markets Care About the $\$ 2.4$ Trillion U.S. Deficit?," Financial Analysts Journal, 63(2), 37-47.

Hamilton, A. (1787): "The Utility of the Union as a Safeguard Against Domestic Faction and Insurrection," The Federalist Papers No. 9, November 21, from http://www.constitution.org/fed/federa09.htm.

Hassett, K., and G. Metcalf (1999): "Investment with Uncertain Tax Policy: Does Random Tax Policy Discourage Investment," The Economic Journal, 109(457), 372-393.

Huggett, M., and G. Ventura (1999): "On the Distributional Effects of Social Security Reform," Review of Economic Dynamics, 2(3), 498-531.

İmrohoroĞLu, A., S. İmrohoroĞLu, And D. H. Joines (1995): "A Life Cyle Analysis of Social Security," Economic Theory, 6(1), 83-114.

- (1999): "Social Security in an Overlapping Generations Model with Land," Review of Economic Dynamics, 2(3), 638-665.

International Monetary Fund (2009): "Fiscal Implications of the Global Economic and Financial Crisis," IMF Staff Position Note SPN/09/13.

Juessen, F., L. Linnemann, and A. Schabert (2009): "Default Risk Premia on Government Bonds in a Quantitative Macroeconomic Model," Tinbergen Institute Discussion Paper TI 2009-102/2. 
Karantounias, A., L. Hansen, and T. Sargent (2009): "Managing Expectations and Fiscal Policy," Federal Reserve Bank of Atlanta Working Paper No. 2009-29.

Kotlikoff, L. J., K. Smetters, and J. Walliser (1998a): "The Economic Impact of Transiting to a Privatized Social Security System," in Redesigning Social Security, ed. by H. Siebert, p. 327. Kiel University Press, Kiel.

(1998b): "Social Security: Privatization and Progressivity," American Economic Review, 88(2), 137-141.

— (2007): "Mitigating America's Demographic Dilemma by Pre-Funding Social Security," Journal of Monetary Economics, 54(2), 247-266.

Leeper, E. M. (1991): 'Equilibria Under 'Active' and 'Passive' Monetary and Fiscal Policies," Journal of Monetary Economics, 27(1), 129-147.

- (2010): "Monetary Science, Fiscal Alchemy," forthcoming in Federal Reserve Bank of Kansas City's Jackson Hole Symposium, Macroeconomic Challenges: The Decade Ahead.

LeePer, E. M., And T. Zha (2003): "Modest Policy Interventions," Journal of Monetary Economics, 50(8), 1673-1700.

Lucas, R., And N. Stokey (1983): "Optimal Fiscal and Monetary Policy in an Economy without Capital," Journal of monetary Economics, 12(1), 55-93.

McCallum, B. T. (1984): “Are Bond-Financed Deficits Inflationary?," Journal of Political Economy, 92(February), 123-135.

Organization for Economic Co-operation and Development (2009): “Tax Database," Table I.7.

Reinhart, C. M., and K. S. Rogoff (2009): This Time is Different: Eight Centuries of Financial Folly. Princeton University Press, Princeton, NJ.

Richter, A. W. (2011): "Understanding the Fiscal Limit in the Presence of Non-Ricardian Consumers," Manuscript, Indiana University.

Sargent, T. J. (2006): "Ambiguity in American Monetary and Fiscal Policy," Japan E The World Economy, 18(3), 324-330.

Sargent, T. J., And N. Wallace (1981): "Some Unpleasant Monetarist Arithmetic," Federal Reserve Bank of Minneapolis Quarterly Review, 5(Fall), 1-17. 
Schabert, A. (2010): "Monetary Policy Under a Fiscal Theory of Sovereign Default," Journal of Economic Theory, 145(2), 860-868.

Sims, C. A. (1982): "Policy Analysis with Econometric Models," Brookings Papers on Economic Activity, 1, 107-152.

- (1987): "A Rational Expectations Framework for Short-Run Policy Analysis," in New Approaches to Monetary Economics, ed. by W. A. Barnett, and K. J. Singleton, pp. 293-308. Cambridge University Press, Cambridge, UK.

(1994): "A Simple Model for Study of the Determination of the Price Level and the Interaction of Monetary and Fiscal Policy," Economic Theory, 4(3), 381-399.

(2011): "Stepping on a Rake: The Role of Fiscal Policy in the Inflation of the 1970's," European Economic Review, 55(1), 48-56.

Smetters, K., And J. Walliser (2004): "Opting Out of Social Security," Journal of Public Economics, 88(7-8), 1295-1306.

Sturzenegger, F., And J. Zettelmeyer (2006): Debt Defaults and Lessons from a Decade of Crises. MIT Press, Cambridge, MA.

Trabandt, M., and H. Uhlig (2009): "How Far Are We From the Slippery Slope? The Laffer Curve Revisited," NBER Working Paper No. 15343.

United Nations (2008): World Population Prospects: The 2008 Revision. United Nations, New York.

URIBE, M. (2006): "A Fiscal Theory of Sovereign Risk," Journal of Monetary Economics, $53(8), 1857-1875$.

Walsh, C. E. (2003): Monetary Theory and Policy. MIT Press, Cambridge, MA, second edn.

Woodford, M. (2001): "Fiscal Requirements for Price Stability," Journal of Money, Credit, and Banking, 33(3), 669-728.

YAARI, M. E. (1965): "Uncertain Lifetime, Life Insurance, and the Theory of the Consumer," The Review of Economic Studies, 32(2), 137-150. 